https://doi.org/10.52058/2786-4952-2022-2(7)-755-768

Швець Оксана Вікторівна кандидат педагогічних наук, доцент кафедри теорії і методики дошкільної та початкової освіти Кременецької обласної гуманітарно-педагогічної академії ім. Тараса Шевченка, Кременецька обласна гуманітарно-педагогічна академія ім. Тараса Шевченка, вул. Ліцейна, 1, м. Кременець, 47003, тел.: (098) 831-76-71, https://orcid.org/0000-0001-7120-9299.

\title{
ДИСТАНЦЙНЕ НАВЧАННЯ ЯК ЗАСІБ ФОРМУВАННЯ ПРОФЕСІЙНОЇ КОМПЕТЕНТНОСТІ МАЙБУТНІХ ВИХОВАТЕЛІВ ЗАКЛАДІВ ДОШКІЛЬНОЇ ОСВІТИ
}

Анотація. У статті актуалізована проблема професійної підготовки майбутніх вихователів закладів дошкільної освіти (надалі - ЗДО) засобами дистанційної освіти, окреслено специфіку використання дистанційного навчання задля формування їхньої професійної компетентності. Авторка статті наголошує, що COVID-19 ще більше стимулював розвиток інноваційних технологій, в тому числі зумовив перехід здобуття вищої освіти в дистанційний режим, 3 використанням різноманітних форм та методів дистанційного навчання.

Формування професійної компетентності майбутніх вихователів ЗДО засобами дистанційного навчання $є$ важливим завданням сьогодення та має за мету використання технологій дистанційного навчання задля становлення соціально активного, креативного та творчого вихователя ЗДО $з$ високими моральними цінностями, який володіє педагогічними знаннями й уміннями, готовий реалізувати їх на практиці, володіє високим рівнем компетентності.

Авторка розглядає дистанційне навчання як інноваційну педагогічну технологію, яка грунтується на сучасних досягненнях у галузі IКТ та на принципах самоосвіти. За умов дистанційного навчання важливими складовими професійної підготовки майбутніх вихователів ЗДО є розвиток аналітичного та критичного мислення; високого рівня мотивації, розпізнавання та оцінка інформації, аргументів; встановлення інтерактивного спілкування між здобувачем освіти і викладачем без забезпечення їх безпосередньої зустрічі (в режимі онлайн) та самостійне усвідомлене засвоєння компетенцій за обраним курсом на основі використання ІКТ, спрямоване на отримання нових освітніх результатів та оволодіння цифровою грамотністю. Схарактеризовано етапи розвитку дистанційної освіти в контексті професійної підготовки майбутніх вихователів. Наголошено, що сучасні засоби навчання відіграють важливу роль під час організації особистісної продуктивної діяльності того, хто навчається, оскільки відбуваються інтеграція різного роду технологій: інформаційних, психолого-педагогічних. Вище вказане дає змогу забезпечити інтерактивність 
взаємодії викладача та здобувачів освіти і сприяє ефективності організованого дистанційного навчання, освітнього процесу. Окреслено також педагогічні умови ефективної суб'єкт-суб'єктної взаємодії викладача та студента у формуванні професійної компетентності під час реалізації дистанційного навчання.

Ключові слова: дистанційне навчання, професійна підготовка, професійна компетентність, вихователь закладу дошкільної освіти, синхронний режим, асинхронний режим, заклад вищої освіти, педагогічна умова, дистанційна освіта.

Shvets Oksana Viktorivna Candidate of Pedagogical Sciences, Associate Professor of the Department of Theory and Methods of Preschool and Primary Education of Kremenets Regional Humanitarian and Pedagogical Academy named after Taras Shevchenko, Kremenets, Kremenets Regional Humanitarian and Pedagogical Academy named after Taras Shevchenko, Lyceum St., 1, Kremenets, 47003, tel.: (098) 831-76-71, https://orcid.org/0000-0001-7120-9299.

\section{DISTANCE LEARNING AS A MEANS OF FORMING PROFESSIONAL COMPETENCE OF FUTURE TEACHERS OF PRESCHOOL EDUCATION INSTITUTIONS}

Abstract. The article actualizes the problem of professional training of future educators of preschool education institutions (hereinafter - ZDO) by means of distance education, outlines the specifics of using distance learning to form their professional competence. The author of the article emphasizes that COVID-19 has further stimulated the development of innovative technologies, including the transition of higher education to distance learning, using a variety of forms and methods of distance learning. Formation of professional competence of future educators of distance learning by means of distance learning is an important task today and aims to use distance learning technologies to become a socially active, creative and creative educator with high moral values, who has pedagogical knowledge and skills, ready to implement them in practice high level of competence.

The author considers distance learning as an innovative pedagogical technology based on modern achievements in the field of ICT and the principles of selfeducation. Under the conditions of distance learning, the development of analytical and critical thinking is an important component of professional training of future educators; high level of motivation, recognition and evaluation of information, arguments; establishing interactive communication between the student and the teacher without providing a direct meeting (online) and self-conscious acquisition of competencies in the chosen course based on the use of ICT, aimed at obtaining new educational outcomes and mastering digital literacy. The stages of development of distance education in the context of professional training of future educators are characterized. It is emphasized that modern teaching aids play an important role in the 
organization of personal productive activities of the learner, as there is an integration of various technologies: information, psychological and pedagogical. The above allows to ensure the interactivity of interaction between teachers and students and contributes to the effectiveness of organized distance learning, the educational process. The pedagogical conditions of effective subject-subject interaction of teacher and student in the formation of professional competence during the implementation of distance learning are also outlined.

Keywords: distance learning, professional training, professional competence, educator of preschool education institution, synchronous mode, asynchronous mode, higher education institution, pedagogical condition, distance education.

Постановка проблеми. В Україні розпочато процес модернізації професійної підготовки майбутніх вихователів, зумовлений на формування здатності швидко адаптуватися до нових вимог та підвищення якості освітньої діяльності в закладах дошкільної освіти (надалі - ЗДО), спроможних розширювати власні межі володіння науково обгрунтованими інноваційними педагогічними й інформаційними технологіями. Започатковані ці зміни давно, однак набувають нового переосмислення у зв'язку із виходом Професійного стандарту вихователя ЗДО (2021) [7]. Загальновідомо, що саме дошкільна освіта повинна швидко реагувати на сучасні культурні запити, збагачувати знання дитини необхідною інформацією, допомагати їй реалізовувати свої природні задатки та здібності, бути зорієнтованою на загальнолюдські й національні цінності. Базовий компонент дошкільної освіти (2021) започаткував запровадження нового змісту дошкільної освіти, забезпечивши наступність між дошкільною та початковою освітою. Всі ці факти зумовлюють та актуалізують необхідність підвищення вимог до майбутніх вихователів та необхідність удосконалення їх професійної підготовки засобами сучасних методів та технологій, спрямованих на оновлення системи освіти відповідно до вимог часу, надбань науки, культури і практики. Розвиток педагогічної освіти в Україні засвідчує, що ефективним та результативним $є$ той освітній процес, який забезпечений теоретико-методологічними, дидактично-методичними розробками, які відповідають сучасним вимогам науки і практики та мають практичний досвід, відображений в практичних кейсах. Такого роду забезпечення освітнього процесу називають науково-методичним і воно у 3ВО це якісно впливає на професійне становлення майбутнього вихователя ЗДО. В умовах розвитку пандемії в Україні та за рубежем актуальними $є$ технології дистанційного навчання та дистанційної освіти. Пандемія COVID-19 ще більше стимулювала розвиток інноваційних технологій, в тому числі зумовила перехід здобуття вищої освіти в дистанційний режим, з використанням різноманітних форм та методів дистанційного навчання. В Україні наразі відбувається дистанційна професійна підготовка майбутніх вихователів ЗДО, що передбачає використання нових пріоритетів у вимогах до компетентностей, форм та методів роботи викладачів закладів вищої освіти по всій Україні та за кордоном. 
Журнал«Герспективитаінновації науки

(Серія «Гедагогіка», Серія «Гиихологія», Серія «Медицин»»

№2(7) 2022

Аналіз останніх досліджень і публікацій. У вищій школі результати професійної підготовки науковці трактують у площині категорій «компетенція» та «компетентність». Під «компетенцією» розглядають вимоги до освітньої підготовки (у відповідності до стандарту), опис повноважень, окреслення сфери діяльності, потенційні професійні можливості особистості (В. Артеменко, С. Антонщук, X. Алієв, В. Бабійчук, С. Безсмертний, К. Бугайчук, I. Блощинський, А. Заблоцький, I. Зимня, А. Дорофєєв, Н. Копилова, I. Войтович, Н. Власенко, Б. Кремінський, Л. Кравцова, Т. Кравчинська та ін.) [1, с. 38]. У психолого-педагогічній літературі [2, с. 26; 9, с. 317] «компетентність» трактується як підготовленість і реалізована здатність суб'єкта праці до виконання завдань і обов'язків щоденної діяльності, що охоплює знання, вміння, цінності, ставлення та досвід поведінки особистості. Професійна компетентність - вид компетентності, що характеризує особистість в контексті виконання нею професійних обов'язків [3, с. 27]. Наукові пошуки I. Беха, А. Богуш, А. Букач, В. Бенери, А.Бєлєнької, В. Бондаря І. Зязюна, А. Заблоцького та Т. Танько й ін. підводять до думки, що поняття професійної педагогічної компетентності є складнішим, ніж загальне поняття «професійна компетентність», з чим ми погоджуємося [2, с. 30]. Використання у практичній діяльності ідей та методів дистанційного навчання (надалі - ДН) досліджують: О. Андрєєв, В. Солдаткін, С. Полат, М. Бухаркіна, В. Кухаренко, В. Биков, Н. Сиротенко, О. Рибалко, Ю. Богачков, П. Федорук, Г. Козлакова та ін. [1, с. 36]. Теоретичні аспекти організації ДН знайшло своє відображення у монографіях: Г. Козлакової, В. Гриценка, С. Кудрявцевої, В. Колос, В. Веренич, С. Сисоєвої, А. Алексюк, П. Воловик; у роботах на здобуття ступеня доктора філософії: О. Собаєвої, Т. Койчевої, А. Мушака, О. Хмель, Є. Владимирської, та ін. [8, с. 28]. Питання організації освітнього процесу в контексті застосування ДН в закладах вищої освіти окреслені в наукових розвідках вітчизняних та зарубіжних вчених: В. Свиридюк, Н. Басова, Д. Бодненко, Н. Домаскіна, Н. Жевакіна, О. Кіріленко, А. Кузьмінський, А. Хуторський, Б. Шуневич, Г. Яценко та ін. [4, с. 161]. Психолого-педагогічні аспекти ДН представлені в наукових працях (Р. Гуревич, Ю. Овод, О. Кареліна, Р. Шаран, Є. Долинського, В. Олійник, П. Стефаненко, 3. Курлянд, Р. Хмелюк тощо [5, с. 303]. Зарубіжні дослідження в галузі організації ДН: А. Сагателян, Н. Фредеріксон, Ф. Рід, В. Кліффорд, С. Гурі-Розенбліт, М. Мур, Д. Кіген, Ч. Ведемеєр, О. Петерс, У. Пері, Дж. Даніель, У. Макінтош, У. Діл $[9$, с. 330]. Аналіз змісту педагогічної підготовки майбутніх вихователів у зарубіжних країнах (США, Італії, Німеччині та ін.) свідчить про те, що за незначної кількості теоретичних знань у закладах вищої освіти пропонують чимало онлайн курсів, започатковані віртуальні університети для підготовки майбутніх вихователів ЗДО, які дають змогу, використовуючи Інтернет технології мати доступ до онлайн-бібліотек, практичних кейсів до тем, що вивчає здобувач, працювати в зручний час з будь якої точки світу [5, с. 307]. Однак, залишаються не до кінця з'ясованими особливості використання дистанційного навчання під час підготовки вихователів закладів дошкільної 
освіти, не визначені педагогічні умови забезпечення цього процесу в закладах вищої освіти (надалі - ЗВО). Мета публікації - теоретично обгрунтувати та охарактеризувати педагогічні умови викорисатння дистанційного навчання у формуванні професійної компетентності майбутніх вихователів ЗДО.

Виклад основного матеріалу. Вітчизняна освітня галузь щоденно зазнає кардинальних змін, які спрямовані на інтеграцію до європейського освітнього простору та передбачають удосконалення форм та методів навчання у професійній підготовці майбутніх фахівців дошкільної освіти. Пріоритетним орієнтиром освітніх реформ виступає підвищення якості надання освітніх послуг у ЗВО. У цих умовах національна система вищої освіти постала перед необхідністю значного підвищення професійної компетентності педагогів, професійного розвитку та саморозвитку. Підготовка майбутніх вихователів ЗДО актуальна в сучасній педагогічній теорії та практиці України («Про освіту» (2017) і «Про вищу освіту» (2014), «Концепції розвитку педагогічної освіти» (2018). Означені нормативно-правові документи зумовлюють необхідність забезпечення якісної професійної підготовки, як основи для формування конкуретноспроможного на ринку праці фахівця в галузі дошкільної освіти.

Професійна компетентність майбутнього вихователя ЗДО - результат теоретичної та практичної підготовленості особистості до здійснення педагогічної діяльності, що відображається єдністю загальнопедагогічних, спеціальних, технологічних, комунікативних i рефлексивних компетенцій i зазвичай відображається у результатах навчання та в здатності самостійно, відповідально, якісно, швидко та ефективно виконувати функції, передбачені посадовою інструкцією. Провідною педагогічною умовою формування професійної компетентності майбутнього вихователя ЗДО $\epsilon$ наявність професійно значущої мотивації, професійного інтересу, позитивного ставлення до обраної професії. Так, компетентність зумовлює необхідність наявності в здобувача вищої освіти внутрішньої мотивації. Зауважимо, що якщо вона присутня, то це, позитивно впливає на успішність його розвитку, навчання i становлення як фахівця. Формування професійної компетентності майбутніх вихователів ЗДО засобами дистанційного навчання $є$ важливим завданням сьогодення. Цей вид навчання розглядають як певний узагальнений показник професіоналізму, тобто, як уміння вихователя вільно орієнтуватися в складних умовах професії, зумовлених пандемією, вміти оперувати суб'єктивними й об'єктивними іiі складовими, застосовувати нові способи здійснення своєї діяльності, використовувати дистанційні технології.

Затвердження Стандарту «Вихователь закладу дошкільної освіти» (2021) [7] актуалізував потребу в удосконаленні професійної підготовки майбутніх вихователів у ЗВО з орієнтацією на нові пріоритетні завдання, компетентності, передбачені нормативно-правовим документом. Окреслення концептуальних засад формування професійної компетентності майбутніх вихователів закладів дошкільної освіти в умовах ДО здійснюватимемо із опорою на сучасні дослідження науковців, зупинившись на аналізі праць Г. Бєленької, 
І. Ліпчевської, О. Мисик, О. Половіної, Д. Соммер та ін. науковців [4, с. 202]. Перед вищою педагогічною школою України стоїть завдання підготовки технологіями ДН конкурентоспроможних майбутніх вихователів ЗДО: поєднати загальні та фахові компетентності шляхом включення здобувачів вищої освіти в активну діяльність за змістом обраної спеціальності. Ми розглядаємо формування професійної компетентності майбутнього вихователя ЗДО із врахуванням взаємозв'язку принципу єдності свідомості й діяльності: професійна свідомість розглядається як його теоретична готовність до професійної діяльності, що спрямовує професійну діяльність як практичну підготовленість вихователя до виконання фахових обов'язків. Здатність майбутнього вихователя ЗДО самостійно й ефективно досягати цілей своєї професійної діяльності - це результат системного формування професійної свідомості в єдності з досвідом професійної діяльності.

Становлення педагога в особистісному та професійному плані відбувається протягом навчання від першого по четвертий курс і надалі впродовж професійної діяльності. Цей процес, на думку М. Машовець та М. Науменко, залежить від формування у нього професійної позиції - визначення свого становища в системі відносин із колегами й дітьми; набуття власного когнітивного стилю, професійного розвитку (зростання інтелектуальних i творчих здібностей, особистісної культури психічної діяльності), виділення часу та сили для особистісного розвитку, подолання негативних суб'єктивних факторів в освіті [6, с. 42]. За час навчання у ЗВО формуються моральні установки й ціннісні орієнтації, що якісно відрізняє кожного зі студентів. Базовими характеристиками та основою розвитку особистості майбутнього фахівця в галузі дошкільної освіти є: особистісна педагогічна спрямованість, гнучкість, відкритість до нового. Наголосимо, що від компетентності й професіоналізму викладачів у ЗВО, які вибудовують взаємодію зі студентами на дослідницьких та практико орієнтованих засадах, а також від освітніх умов 3ВО прямо залежить якість освітньої діяльності здобувачів вищої освіти та набуття ними конкурентоспроможних здатностей [2, с. 42]. Науковиця Л. Карамушка обгрунтувала, що для ефективного реагування на освітні запити суспільства в сучасних умовах, ЗВО мають відповідати певним вимогам: а) вміти швидко реагувати на зміни, що відбуваються у суспільстві та модифікувати свою діяльність; б) швидко адаптуватися до нових змін у суспільстві та транслювати їх у новий зміст та технології навчання, стратегії взаємодії між учасниками освітнього процесу, нові індивідуально-психологічні характеристики суб'єктів такої взаємодії; в) ЗВО має бути організацією, яка охоплює особистості, що постійно навчаються новому та мають такі риси: стратегічно мислять і здатні прогнозувати майбутнє; володіють сильною корпоративною культурою; командним принципом роботи й вільним обміном інформацією на партнерських засадах; г) функціонувати та розвиватися на засадах гуманістичного та оптимістичного менеджменту, враховувати специфіку діяльності (навчання, виховання й розвиток особистості майбутнього фахівця) [2, с. 39]. 
Зміст професійної освіти майбутніх вихователів ЗДО відображає завдання та потреби суспільства, а також характеризується сукупністю вимог, які будуть пред'являтися до них у майбутній професійній діяльності. Формування професійної компетентності майбутнього вихователя ЗДО в умовах дистанційної освіти має за мету використання технологій ДН задля становлення соціально активного, креативного та творчого вихователя ЗДО з високими моральними цінностями, який володіє педагогічними знаннями й уміннями, готовий реалізувати їх на практиці, володіє високим рівнем компетентності [3, с. 33].

ДН - це інноваційна педагогічна технологія, яка грунтується на сучасних досягненнях у галузі IКТ та грунтується на принципах самоосвіти [4, с. 94]. Представимо в рис. 1. Особливості формування професійної компетентності майбутніх вихователів ЗДО під час навчання у ЗВО в умовах пандемії.

ДН визначається як таке, що передбачає одержання освітніх послуг на відстані (здебільшого без відвідування ЗВО) за допомогою використання комп'ютерних i комунікаційних технологій i водночас $\epsilon$ універсальною, інтегративною формою навчання. Перевага ДН за вище викладеного стану - це наявність умов для здобувачів вищої освіти, адаптованих до їхнього базового рівня знань і мети навчання [2, с. 151]. Якість роботи майбутнього вихователя ЗДО залежить не тільки від освітніх програм та матеріально-технічного забезпечення ЗДО, а в першу чергу від рівня сформованої його особистості, індивідуальних базових цінностей, культури, його професійних вмінь і навичок, взаємин 3 колегами, вихованцями, їх батьками, здатності до професійної рефлексії. 


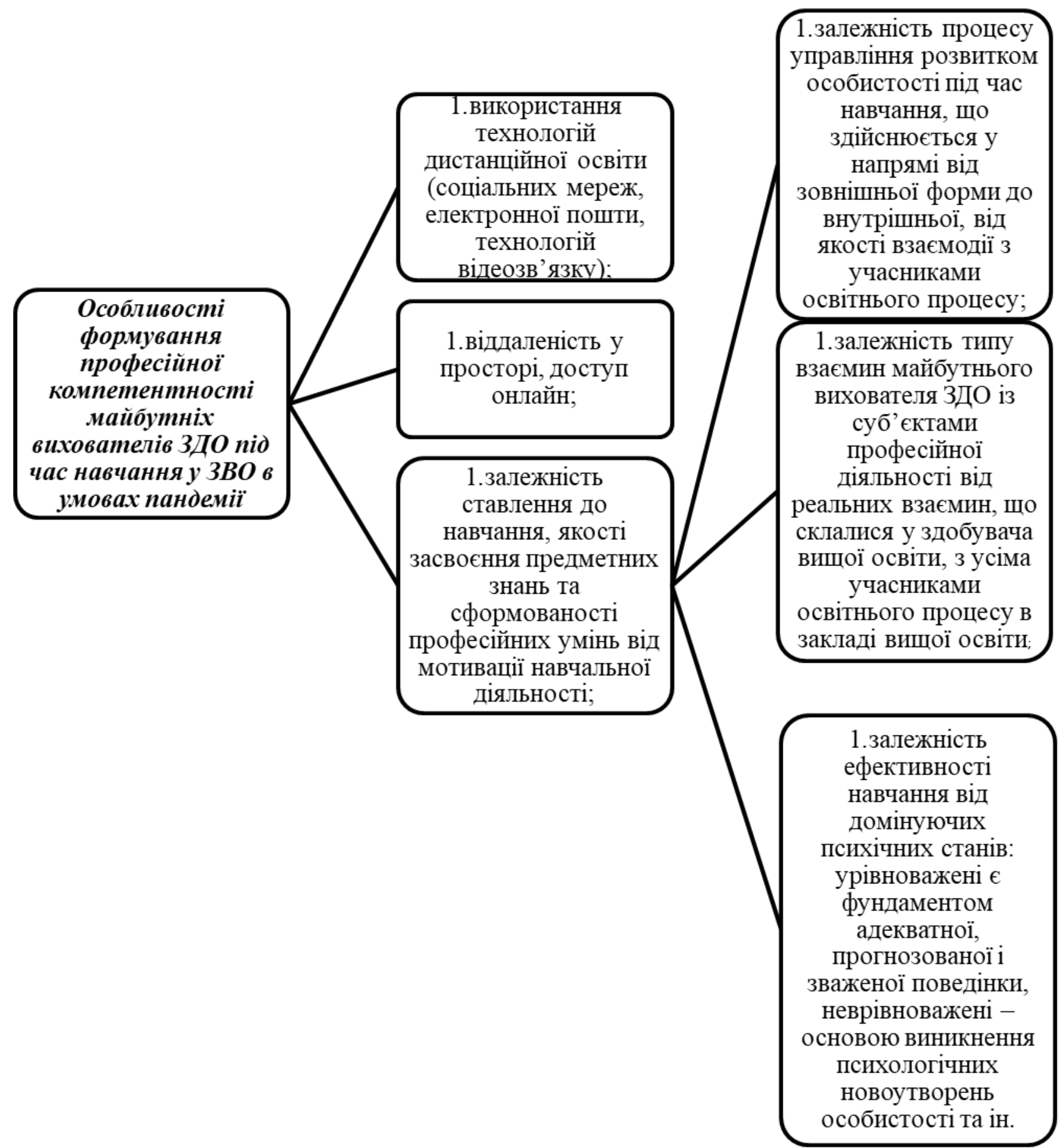

Pис.1. Особливості формування професійної компетентності майбутніх вихователів ЗДО під час навчання у ЗВО в умовах пандемії [1-9]

Гуманістичні тенденції в галузі освіти зорієнтовують сучасного вихователя ЗДО на постійне самовдосконалення, професійний саморозвитку і самоосвіту, бо лише за таких умов він буде здатним ефективно та якісно поєднувати теоретичні знання та практичні вміння; своєчасно впроваджувати досвід традиційної та емпіричної педагогіки; бути обізнаним в сучасних проблемах дошкільної освіти та шляхах їх вирішення; знати та застосовувати сучасні технології, методики та активно впроваджувати власні педагогічні доробки в 
практику роботи; бути ефективним та критичним відповідно до ситуації, здійснювати об'єктивну самооцінку власної педагогічної діяльності. Використання ДО задля реалізації вище вказаного завдання - вимога часу. Саме застосування потенціалу ДО дає змогу в режимі онлайн опановувати найновішу інформації з актуальних питань для саморозвитку, збагачуватись новими навичками під час спілкування з успішними та відомими людьми в дошкільній галузі через участь у вебінарах, відеокоференціях, марафонах тощо. Отож, можна дійти висновку, що організація дистанційної освіти під час професійної підготовки майбутніх вихователів ЗДО $є$ важливою складовою і відповідає сучасним запитам в освітній сфері. На основі аналізу наявної літератури можна констатувати, що в своєму розвитку технологія ДО пройшла кілька етапів, які представимо в таблиці 1.

Табличя 1.

Етапи розвитку ДО в контексті професійної

підготовки майбутніх вихователів ЗДО [1;2; 4; 5; 8]

\begin{tabular}{|c|c|}
\hline $\begin{array}{l}\text { Назва } \\
\text { етапу }\end{array}$ & Характерні риси розвитку дистанційної освіти \\
\hline $\begin{array}{l}\text { Перший } \\
\text { етап }\end{array}$ & $\begin{array}{l}\text { взаємодія здійснюється за схемою педагог-здобувач/i освіти. } \\
\text { Використовують такі види зв'язку: пошта, телефон, комп'ютер. } \\
\text { На цьому етапі кількість учасників ДО невелика і компоненти ії } \\
\text { забезпечення автономні, незалежні один від одного. Характерна } \\
\text { риса: відсутня системність і комплексність в застосуванні засобів } \\
\text { ДН. }\end{array}$ \\
\hline $\begin{array}{c}\text { Другий } \\
\text { етап }\end{array}$ & $\begin{array}{l}\text { взаємодія, передбачає викладача та чимало студентів. Передача } \\
\text { знань іде від викладача до студентів. Види зв’язку між навчальною } \\
\text { інформацією здійснюються та розширюються за рахунок відео та } \\
\text { аудіокасет, комп'ютерних програм, супутникового телебачення та } \\
\text { інших засобів дистанційного навчання. }\end{array}$ \\
\hline $\begin{array}{l}\text { Третій } \\
\text { етап }\end{array}$ & $\begin{array}{l}\text { дистанційне навчання стрімко розвивається, збільшується число } \\
\text { користувачів мережі Інтернет, становить більше } 100 \text { мільйонів } \\
\text { людей. Науковці працюють над засобами і формами } \\
\text { дистанційного навчання, освіта стає більш доступною у зручний } \\
\text { час для бажаючих вчитися. }\end{array}$ \\
\hline $\begin{array}{c}\text { Четвертий } \\
\text { етап }\end{array}$ & $\begin{array}{l}\text { характеризується комплексним використанням засобів доставки } \\
\text { інформації: інтеграції радіо, телефону, комп'ютерних мереж, } \\
\text { супутникового і кабельного відеозв'язку. Кожна країна починає } \\
\text { виробляти власний шлях впровадження технології ДН, враховуючи } \\
\text { матеріальні ресурси країни а ії інтелектуальний потенціал. }\end{array}$ \\
\hline
\end{tabular}

Сучасні засоби навчання відіграють важливу роль під час організації особистісної продуктивної діяльності того, хто навчається, оскільки відбуваються інтеграція різного роду технологій: інформаційних, психологопедагогічних. Вище вказане дає змогу забезпечити інтерактивність взаємодії 
викладача та здобувачів освіти і сприяє ефективності організованого ДН, освітнього процесу. ДН передбачає одержання освітніх послуг на відстані, без відвідування 3ВО, а шляхом використання IКТ, доступу до Інтернету.

Різні науковці по-різному трактують ДН. А. Андрєєв ДН розглядає, як синтетичну інтегровану форму навчання, яка основана на застосуванні традиційних та нових інформаційних технологій. Наприклад, Є. Долинський вбачає в ДН не лише форму здобуття освіти, а й спосіб застосування в освітньому процесі кращих традиційні та інноваційні засобів; форму навчання, що грунтується на IKT та телекомунікаційних технологіях [8, с. 113]. Науковець П. Федорук розкриває ДН як нову організацію освітнього процесу, і наголошує, що використання СДН та апробація мультимедійних засобів дозволяють зберегти якість традиційних технологій передачі знань i забезпечити підвищення результатів навчання здобувачів вищої освіти [2, с. 12]. Згідно 3 дослідженням Р. Шаран, ДН - це самостійна педагогічна технологія, базисом якої $\epsilon$ самостійна робота студентів (керована, дидактично забезпечена та контрольована); із застосуванням у навчанні мережі Інтернет [4, с. 17].

В умовах сьогодення розвиток ДО відбувається більш активно i супроводжується зміною підходів до вибору форм та методів ДН, враховуючи специфічні умови кожного конкретного ЗВО та його здобувачів. Спираючись на ці підходи, ми з'ясували, що важливими константами професійної підготовки майбутніх вихователів ЗДО за умов дистанційного навчання $є$ :

1. розвиток аналітичного та критичного мислення здобувачів освіти;

2. формування високої мотивації, уміння обирати з інформаційного потоку необхідну інформацію, оцінювати ії та засвоювати;

3. встановлення суб'єкт-суб'єктної взаємодії, інтерактивного спілкування між здобувачем вищої освіти i викладачем без забезпечення їхньої безпосередньої зустрічі, самостійне освоєння певного масиву знань і навичок за обраним студентом курсом на основі використання IКТ, результат взаємодії отримання нових освітніх результатів [4, с. 66]. Таким чином, 3ДО потребують висококваліфікованих, конкурентноспроможних вихователів ЗДО, що характеризуються високими здібностями, внутрішньою мотивацією до здійснення обраного напрямку професійної діяльності, постійно прагнуть до самовдосконалення та професійного саморозвитку, успішно застосовують теоретичні знання в практичній діяльності, засвоїли сучасні технології та методики, володіють навичками Soft Skills та здатні до інноваційної діяльності. 3 огляду на це, є підстави вважати, що удосконалення дошкільної освіти в Україні повинно враховувати запити здобувачів вищої освіти та водночас вирішувати актуальні цієї освітньої галузі: підвищувати рівень професіоналізму усіх учасників освітнього процесу засобами технологій ДН.

За умов ДН важливими складовими професійної підготовки майбутніх вихователів ЗДО є розвиток аналітичного та критичного мислення; високого рівня мотивації, розпізнавання та оцінка інформації, аргументів; встановлення інтерактивного спілкування між здобувачем освіти i викладачем без 
забезпечення їх безпосередньої зустрічі (в режимі онлайн) та самостійне усвідомлене засвоєння компетенцій за обраним курсом на основі використання IКТ, спрямоване на отримання нових освітніх результатів та оволодіння цифровою грамотністю. Важливим компонентом освітнього процесу для будьякого навчання є комунікація і від ії рівня залежить ефективність ДН. Взаємодія між викладачами і студентами в ДН відбувається в межах штучно створеного комунікативного простору, який зумовлює сформовану ситуацію взаємодії, в якій $є$ місце, час та взаємне бажання для спілкування, що базуються на досягненні завдань освітнього процесу. В умовах ДН цей процес ускладняється, зумовлює необхідність спільної взаємопов'язаної діяльності, сприйняття та розуміння інших у віртуальному просторі. Виділяємо два режими ДН, які представимо в рис. 2.

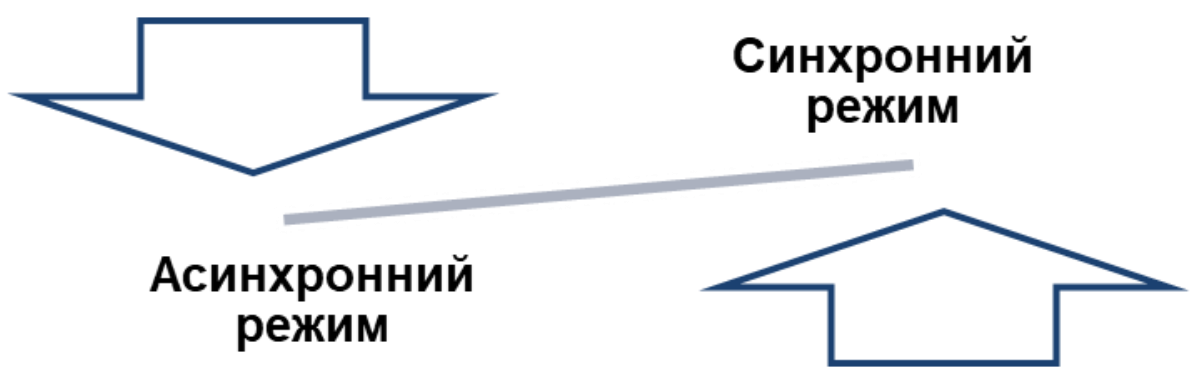

Pис. 2. Режими дистанційного навчання [9, с. 318]

Так, співпрацювати в режимі реального часу дозволяє синхронний режим. Його перевага полягає в тому, що можна залучати учасників миттєво та у визначений час. Не потрібно копіювати аудиторну систему в онлайн форматі, бо під час дистанційного заняття ефективніше запланувати свою діяльність: мінімум пояснень, максимум інтерактиву. Асинхронний режим передбачає використання різноманітні засоби інформації, аудіо- та відеоуроки (але не обмежуватись ними). За допомогою такого режиму навчання студент може працювати у власному темпі та в зручний для себе час. Викладачеві важливо зазначити терміни виконання завдань, надіслані для зворотного зв'язку, надати розклад занять для студентів, щоб вони могли планувати свій день. Асинхронний режим відіграє важливу роль під час різних форм цифрового та онлайнового навчання. Наприклад, викладач може записувати власні короткі відеоуроки, пояснення або навчальні завдання на основі ігор, які студенти виконують самостійно. Асинхронний режим включає: записані мультимедійні презентації, слайд-шоу та відео; електронну пошту; оналайн-дошки для обговорень; тестові завдання, відеоролики та відеозвернення, створення груп в соціальних мережах або Viber $[9$, с. 330]. Зауважимо, що перевагами асинхронного навчання $є$ самостійність, незалежність, гнучкість, диференціація, індивідуальний темп учасників. В асинхронному режимі здобувач освіти може працювати у власному темпі, що складно забезпечити під час синхронного навчанні у ЗВО. Зазначимо, що у виборі режиму навчання зазвичай 
оптимальним є змішаний підхід, який може допомогти викладачеві об'єднати переваги синхронного та асинхронного режимів, а також навчання в різних режимах (онлайн та офлайн). У результаті, здобувачі освіти дотримуються більш-менш звичного для них розкладу, а з іншого - вони не перевантажені онлайн-присутністю викладача, його вимогами та поясненнями. Додатково викладач може запропонувати студенту щоденні зустрічі в конкретний час (для тих здобувачів освіти, кому потрібна консультація). Складністю ДН є не тільки стимулювання та мотивація студентів до розгортання діалогу, який їм дозволяє висловлювати найрізноманітніші пропозиції. Основна мета комунікації полягає в залученні та мотивації учасників до освітнього процесу та активної участі у ньому. Діалог між викладачами і студентами є важливим у ході як письмового, так і усного онлайн-спілкування, щоб студенти відчували належну підтримку та бажання завершити розпочату справу до кінця. При цьому необхідно, щоб студенти отримували якісний зворотний зв'язок (фідбек), це додатковий стимул та мотивація. Під час ДН значну частину свого часу викладач витрачає на підготовку до занять та аналіз власної діяльності. Педагог не мусить працювати цілодобово і має дбати про себе, щоб не допустити професійного вигорання i перевтоми. Якість ефективної суб'єкт-суб'єктної взаємодії значною мірою залежить і від обраних форм онлайн-комунікації (відеоконференція, форум, чат, блог, соціальні мережі, електронну пошту чи ін.).

Серед педагогічних умов ефективної суб'єкт-суб'єктної взаємодії викладача та студента у формуванні професійної компетентності при реалізації дистанційного навчання: забезпечення соціального виміру організації ДН (рівний доступ і закінчення навчання для усіх верств населення); реалізація діалогу у середовищі ЗВО на різних рівнях: суб'єктів, культур, сфер діяльності, внутрішнього; поетапне формування суб'єктної позиції в здобувачів вищої освіти засобами студентоцентрованого навчання; реалізація компетентнісного підходу та активне впровадження IКТ у діяльність 3ВО; проблематизація змісту навчальних дисциплін фахової підготовки за рахунок використання текстів як джерела навчальних та культурних смислів; міжнародна відкритість та мобільність під час реалізації ДН, проведення дистанційних курсів; розробка багатовимірних інструментів прозорості системи ДН, оплати праці, перевірки результатів навчання здобувачів освіти під час ДН та ін.; забезпечення у 3ВО необмежений онлайн доступ до світових наукових цінностей та баз знань; вчити здобувачів та викладачів розширювати коло спілкування для професійного розвитку та оперування інноваціями, розробкою нових інструментів для організації освітнього процесу, ДН та традиційного навчання; впроваджувати інтерактивні форми і методи організації освітнього процесу у середовищі ЗВО та поза ним під час ДН; забезпечувати завдання дослідно-рефлексивного характеру у програмі виробничої практики, щоб закріплювати здатності до суб'єкт-суб'єктної взаємодії не лише в аспекті «викладач-студент» або «студент-викладач», а й у тріаді «викладач-студент-діти» тощо; дуальність освіти: можливість для здобувачів освіти поєднувати навчання та дистанційну роботу з свого домашнього комп'ютера. 
Висновки. 3'ясовано, що професійна компетентність майбутнього вихователя ЗДО - результат теоретичної та практичної підготовленості особистості до здійснення педагогічної діяльності, що відображається єдністю загальнопедагогічних, спеціальних, технологічних, комунікативних i рефлексивних компетенцій і зазвичай відображається у результатах навчання та в здатності самостійно, відповідально, якісно, швидко та ефективно виконувати функції, передбачені посадовою інструкцією. Дистанційне навчання (онлайннавчання) - це інноваційна педагогічна технологія, яка грунтується на сучасних досягненнях у галузі IКT та грунтується на принципах самоосвіти. Встановлено, що важливими константами професійної підготовки майбутніх вихователів ЗДО за умов дистанційного навчання є: розвиток аналітичного та критичного мислення здобувачів освіти; формування високої мотивації, уміння обирати 3 інформаційного потоку необхідну інформацію, оцінювати іiі та засвоювати; встановлення суб'єкт-суб'єктної взаємодії, інтерактивного спілкування між здобувачем вищої освіти і викладачем без забезпечення їхньої безпосередньої зустрічі, самостійне освоєння певного масиву знань і навичок за обраним студентом курсом на основі використання ІКТ, результат взаємодії отримання нових освітніх результатів. Перспективи подальших розвідок вбачаємо в характеристиці особливостей впровадження змішаного навчання в ЗВО, яке є однією з кращих світових практик.

\section{Лimepamypa:}

1. Алієв Х. М. Дистанційні освітні технології: сутність, ознаки, особливості. Педагогічний альманах : зб. наук. пращь / Херсонська акад. неперерв. освіти. Херсон, 2017. Вип. 35. С. 36-40. http://nbuv.gov.ua/UJRN/pedalm_2017_35_7

2. Антощук С. В. Основи організації дистанційного навчання в післядипломній педагогічній освіті: наук. посіб. Суми : НІКО, 2015. 180 с. https://core.ac.uk/download/pdf/218892867.pdf

3. Бєлєнька Г. В. Особливості формування професійної компетентності у студентів дошкільного фаху в умовах ступеневої освіти. Наука і сучасність: зб. наук. пращь НПУ ім. М. П. Драгоманова. К. : Логос, 2001. Т. 29. С. 26-33.

4. Биков В. Ю. Дистанційний навчальний процес: навч. посібн. К. : Міленіум, 2005. 292 с.

5. Бодак Н. Міжнародні стандарти у сфері дистанційного навчання. Геополітика України : історія і сучасність. 2014. Вип. 1. С. 303-309. http://nbuv.gov.ua/UJRN/gpuis_2014_1_23

6. Машовець М. А., Науменко М. С. Формування конкурентно спроможного фахівця дошкільної освіти в умовах євроінтеграції. Молодий вчений. 2017. № 50.2 (10.2). С. $42-46$.

7. Професійний стандарт за професією «Вихователь закладу дошкільної освіти» (2021 p.). Proyekt.prof.stand.Vykhov.ZDO.01.07.pdf (mon.gov.ua)

8. Семенов М. А. Система забезпечення якості дистанційного навчання в умовах відкритої освіти. Вісник Луганського наи. ун-ту ім. Тараса Шевченка. Педагогічні науки. 2017. № 7(1). C. 113-122. http://nbuv.gov.ua/UJRN/vlup_2017_7(1)_14

9. Томаз I. А. Самостійна робота - запорука ефективності дистанційного навчання. Наукові записки кафедри педагогіки. 2019. Вип. 44. С. 317-330.

\section{References:}

1. Aliev, H. M. (2017). Distancijni osvitni tehnologiï: sutnist', oznaki, osoblivosti [Distance educational technologies: essence, signs, features]. Pedagogichnij al'manah - Pedagogical Almanac, 35, 36-40 [in Ukrainian]. 
2. Antoshhuk, S. V. (2015). Osnovi organizaciï distancijnogo navchannja v pisljadiplomnij pedagogichnij osviti [Fundamentals of distance learning in postgraduate pedagogical education: science. way]. Sumy: NIKO [in Ukrainian].

3. Belen'ka, G. V. (2001). Osoblivosti formuvannja profesijnoï kompetentnosti u studentiv doshkil'nogo fahu $v$ umovah stupenevoï osviti [Features of the formation of professional competence in preschool students in terms of higher education]. Nauka i suchasnist' - Science and modernity, 29, 26-33 [in Ukrainian].

4. Bikov, V. Ju. (2005). Distancijnij navchal'nij proces [Distance learning process: textbook]. K. : Milenium [in Ukrainian].

5. Bodak, N. (2014). Mizhnarodni standarti u sferi distancijnogo navchannja [International standards in the field of distance learning]. Geopolitika Ukraïni: istorija i suchasnist' - Geopolitics of Ukraine: history and modernity, 1, 303-309 [in Ukrainian].

6. Mashovec', M. A., Naumenko, M. S. (2017). Formuvannja konkurentno spromozhnogo fahivcja doshkil'noï osviti $\mathrm{v}$ umovah evrointegraciï [Formation of a competitive specialist in preschool education in terms of European integration ]. Molodij vchenij - Young scientist, 50.2 (10.2), 42-46 [in Ukrainian].

7. Profesijnij standart za profesicju «Vihovatel' zakladu doshkil'noï osviti» [Professional standard for the profession "Educator of preschool education"]. Proyekt.prof.stand.Vykhov. ZDO.01.07.pdf. mon.gov.ua. [in Ukrainian].

8. Semenov, M. A.(2017). Sistema zabezpechennja jakosti distancijnogo navchannja v umovah vidkritoï osviti [Quality assurance system for distance learning in open education]. Visnik Lugans'kogo nac. un-tu im. Tarasa Shevchenka. Pedagogichni nauki - Bulletin of the Luhansk National University University named after Taras Shevchenko. Pedagogical sciences, 7(1), 113-122 [in Ukrainian].

9. Tomaz, I. A. (2019). Samostijna robota - zaporuka efektivnosti distancijnogo navchannja [Independent work - the key to the effectiveness of distance learning]. Naukovi zapiski kafedri pedagogiki - Scientific notes of the department of pedagogy, 44, 317-330 [in Ukrainian]. 